\title{
Preparation of Titanium Oxide, Iron Oxide, and Aluminium Oxide from Sludge generated from Ti-salt, Fe-salt and Al-salt Flocculation of Wastewater
}

H.K. Shon ${ }^{\text {a,* }}$, S. Vigneswaran ${ }^{\text {a }}$, J. Kandasamy ${ }^{\text {a }}$, J.-B. Kim ${ }^{\text {b }}$, H.J. Park ${ }^{\mathrm{b}}$, S.W. Choi ${ }^{\mathrm{c}}$ and J.-H. Kim ${ }^{\text {b,d }}$

${ }^{a}$ Faculty of Engineering and Information Technology, University of Technology, Sydney, P.O. Box 123, Broadway, NSW 2007, Australia

${ }^{\mathrm{b}}$ Photo \& Environmental Technology Co. Ltd., Gwangju 500-460, Korea

'Department of Environmental Engineering, Dong-A University, Busan 604-714, Korea ${ }^{\mathrm{d}}$ School of Applied Chemical Engineering \& The Institute for Catalysis Research, Chonnam National University, Gwangju 500-757, Korea

* The author to whom all correspondence should be addressed: hkshon@eng.uts.edu.au

\section{Abbreviated title: Preparation of metal oxides from sludge}

\section{Abstract}

In this study, the settled floc (sludge) produced by aluminum sulfate $\left(\mathrm{Al}_{2}\left(\mathrm{SO}_{4}\right)_{3}\right)$, ferric chloride $\left(\mathrm{FeCl}_{3}\right)$ and titanium tetrachloride $\left(\mathrm{TiCl}_{4}\right)$ flocculation was recycled with a novel flocculation process, which has a significant potential to the lower cost of waste disposal, protect the environment and public health and yield economically useful byproducts. Three coagulants removed $70 \%$ of organic matter in synthetic wastewater. The settled floc was incinerated in the range from $100{ }^{\circ} \mathrm{C}$ to $1000{ }^{\circ} \mathrm{C}$. Alumina $\left(\mathrm{Al}_{2} \mathrm{O}_{3}\right)$, hematite $\left(\mathrm{Fe}_{2} \mathrm{O}_{3}\right)$, titanium oxide $\left(\mathrm{TiO}_{2}\right)$ which are the most widely used metal oxides were produced from the wastewater sludge generated by the flocculation in wastewater with $\mathrm{Al}_{2}\left(\mathrm{SO}_{4}\right)_{3}, \mathrm{FeCl}_{3}$ and $\mathrm{TiCl}_{4}$, respectively. $\mathrm{TiO}_{2}$ particles produced from the sludge 
consisted of the large amount of nano size particles. Hematite $\left(\mathrm{Fe}_{2} \mathrm{O}_{3}\right)$ and grattarolaite $\left(\mathrm{Fe}_{3}\left(\mathrm{PO}_{4}\right) \mathrm{O}_{3}\right.$ or $\left.\mathrm{Fe}_{3} \mathrm{PO}_{7}\right)$ included the majority of micro size (40\%) particles. Alumina $\left(\mathrm{Al}_{2} \mathrm{O}_{3}\right)$ also consisted of micro size (40\%). Due to $\mathrm{TiO}_{2}$ usefulness of the application, detailed characterisation of $\mathrm{TiO}_{2}$ after calcination at different temperatures were investigated in terms of $\mathrm{X}$-ray diffraction, energy dispersive $\mathrm{X}$-ray, surface area and photoactivity.

Keywords: Flocculation, sludge recycling, titanium dioxide, hematite, alumina

\section{Introduction}

Flocculation causes contaminants to coagulate and is one of the most common chemical treatment methods. Flocculation can be used to remove organic matter, which causes trihalomethane formation during disinfection. However, the flocculation process using a coagulant produces a large amount of sludge which reduces the efficiency of wastewater treatment [1]. Most of this sludge is solid waste from which nothing beneficial can be recovered, cannot be reused and requires further treatment such as incineration, landfill, etc. A novel coagulant and/or a novel process that produce less sludge or more reusable sludge offers a solution to many environmental and economic problems associated with sludge handling.

Commonly-used coagulants include aluminum (72\%) and iron salts (23\%) in water treatment plants [2]. Recently, Shon et al. [3] developed a new coagulant which is titanium tetrachloride $\left(\mathrm{TiCl}_{4}\right)$. The alternative coagulant $\left(\mathrm{TiCl}_{4}\right)$ changes into $\mathrm{TiOCl}_{2}$ in 
wastewater. Depending on $\mathrm{pH}$, the $\mathrm{TiOCl}_{2}$ hydrolyses to $\mathrm{Ti}(\mathrm{OH})_{4}$. As the zeta potential of the negatively-charged organic matter is broken by $\mathrm{Ti}(\mathrm{OH})_{4}$, organic matter aggregates with the $\mathrm{Ti}(\mathrm{OH})_{4}$. Here phosphorus and a variety of metal compounds are found in the wastewater. During incineration of the settled floc, $55 \%$ of water and $20 \%$ of organic matter in the wastewater are vaporized and resulting in the compound $\mathrm{TiO}_{2}$. Titanium chloride $\left(\mathrm{TiCl}_{4}\right)$ has widely been used in industry as an intermediate in the production of titanium rutile, titanium oxide and titanium pigments. Importantly, the cost of bulk $\mathrm{TiCl}_{4}$ is comparable to iron chloride or aluminium sulphate so the process offers an efficient and economical alternative for the removal of organic matter and sludge reduction. Furthermore, protocols for the safe handling and use of bulk $\mathrm{TiCl}_{4}$ are well documented [4]. Thus, the $\mathrm{TiCl}_{4}$ flocculation is efficient and economical not only in terms of removal of organic matter, but also reducing the amount of sludge.

The objective of this study is to reduce the sludge produced from a flocculation process and produce useful byproducts by calcination of sludge. Byproducts produced from sludge obtained after $\mathrm{Fe}, \mathrm{Al}$ and Ti-salt flocculation were investigated in term of particle structure, functional group, elemental content and particle size.

\section{Experimental}

\subsection{Synthetic wastewater and organic removal by flocculation}


Flocculation was conducted with different coagulants ( $\mathrm{TiCl}_{4}, \mathrm{FeCl}_{3}$, and $\left.\mathrm{Al}_{2}\left(\mathrm{SO}_{4}\right)_{3}\right)$ with an optimum dose in synthetic wastewater. The composition of the synthetic wastewater is presented in Table 1 [5]. The relative molecular mass of the mixed synthetic wastewater ranged from 300 daltons to about 34100 with the highest fraction of $900-1200$ daltons. Although sodium lignin sulfornate and tannic acid showed the peaks at 12100 and 6300 daltons respectively, the corresponding peaks were not found in the mixed synthetic wastewater. It may be due to aggregations between organic and inorganic compounds in the synthetic wastewater. The samples were stirred rapidly for 1 minute at $100 \mathrm{rpm}$, followed by 20 minutes of slow mixing at $30 \mathrm{rpm}$, and 30 minutes of settling. Organic matter was measured using a Dohrmann Phoenix 8000 UVpersulphate TOC analyzer equipped with an autosampler. All samples were filtered through $0.45 \mu \mathrm{m}$ membrane prior to organic measurement.

Table 1. Constituents of the synthetic wastewater

\subsection{Characterisation of the settled floc (sludge) and byproduct (metal oxide)}

The decantability test with different settled flocs after flocculation was measured using the ratio of floc head in terms of length unit $(\mathrm{cm})$. XRD images (Rigaku, Japan) of anatase and rutile $\mathrm{TiO}_{2}$ photocatalysts to identify the particle structure was investigated. All the XRD patterns were analyzed with MDI Jade 5.0 (Materials Data Inc., USA). UV-VIS-NIR spectrophotometer (Cary 500 Scan, Varian, USA) was used to identify the absorbance range and the band gap of $\mathrm{TiO}_{2}$ incinerated at different temperatures was

calculated. The photocatalytic activity test of $\mathrm{TiO}_{2}$ was investigated under irradiation of 
UV (Sankyo, F10T8BLB, three $10 \mathrm{~W}$ lamps) and visible light (Kumbo, FL10D, three 10W lamps) using the method of photodecomposition of gaseous acetaldehyde. The concentration of acetaldehyde was measured by gas chromatography (Youngin, M600D, Korea). The particle size distribution of metal oxides after calcinations was investigated with a laser particle size analyzer (LS-230, Beckman Coulter, USA). The visual microscopy was used to measure the shape and size of $\mathrm{TiO}_{2}$. SEM/EDX results were investigated. Micromeritics Gemini 2360 analyzer (USA) for BET surface area analysis was used with automatic surface area analyzer.

\section{Results and Discussion}

\subsection{Organic removal by Ti, Fe and Al-salt flocculation and decantability test of the} settled floc

$\mathrm{Fe}, \mathrm{Al}$ and Ti-salt flocculation at optimum concentration using synthetic wastewater was investigated in terms of organic removal (Figure 1). Removals of organic matter by Fe, Al and Ti-salt flocculation were found to be 73\% (13.8 Fe-mg/L), 70\% (16 Al$\mathrm{mg} / \mathrm{L})$ and 70\% (9.8 Ti-mg/L), respectively. Three coagulants had the range of similar organic removal. Figure 2 shows the decantability test with different flocs. Here, the ratio can be defined as floc head in terms of length unit $(\mathrm{cm})$. The Fe floc settled fast down compared with $\mathrm{Ti}$ and Al flocs. The decantability decreased in the order of Fe floc $>\mathrm{Ti}>$ Al. 
Figure 1. Organic removal by different flocculations with synthetic wastewater (initial organic conc. $=11.5 \mathrm{mg} / \mathrm{L})$

Figure 2. Decantability ratio of different flocs

\subsection{XRD patterns of metal oxides obtained after calcination of the settled floc}

Figure 1 shows XRD images to identify the particle crystalline structure after calcination of the settled floc at different temperatures. After $\mathrm{TiCl}_{4}$ flocculation, the anatase pattern was found from more than $600{ }^{\circ} \mathrm{C}$ (Figure 1a). At lower temperature, remaining organic matter interfered $\mathrm{TiO}_{2}$ production. At $1000{ }^{\circ} \mathrm{C}$, the anatase structure changed to rutile. Although there are a lot of compounds in synthetic wastewater, genuine $\mathrm{TiO}_{2}$ crystalline structure was found. In the case of the settled floc after $\mathrm{FeCl}_{3}$ flocculation, the incinerated flocs were found to have different structures (hematite $\left(\mathrm{Fe}_{2} \mathrm{O}_{3}\right)$ and grattarolaite $\left(\mathrm{Fe}_{3}\left(\mathrm{PO}_{4}\right) \mathrm{O}_{3}\right.$ or $\left.\mathrm{Fe}_{3} \mathrm{PO}_{7}\right)$ (Figure 1b). On the other hand, only $\mathrm{Al}_{2} \mathrm{O}_{3}$ was made at $1000{ }^{\circ} \mathrm{C}$ after $\mathrm{Al}_{2}\left(\mathrm{SO}_{4}\right)_{3}$ flocculation (Figure 1c). Interestingly, berlinite $\left(\mathrm{AlPO}_{4}\right)$ could not be made with Al- flocs. These metal oxide by-products produced in such a way are efficient and economical not only in terms of removal of organic matter in wastewater, but also in sludge reduction. As the metal oxides can be produced in significant quantities in wastewater treatment plants, they can also easily meet demands for different metal oxides in other applications such as environmental photocatalysis. 
Figure 3. XRD images a) of the settled floc after $\mathrm{TiCl}_{4}$ flocculation, b) of the settled floc after $\mathrm{FeCl}_{3}$ flocculation (hematite $\left(\mathrm{Fe}_{2} \mathrm{O}_{3}\right)$ : $24^{\circ}, 33^{\circ}, 35^{\circ}, 40.5^{\circ}, 49.4^{\circ}, 54^{\circ}, 57.5^{\circ}, 62.5^{\circ}$, 63.9 $9^{\circ}$ 71.8 $8^{\circ}, 75.3^{\circ}$; grattarolaite $\left(\mathrm{Fe}_{3}\left(\mathrm{PO}_{4}\right) \mathrm{O}_{3}\right.$ or $\left.\mathrm{Fe}_{3} \mathrm{PO}_{7}\right): 18.2^{\circ}, 28.9^{\circ}, 36.8^{\circ}, 38.9^{\circ}$, $43.3^{\circ}, 45.3^{\circ}, 45.6^{\circ}, 49.2^{\circ}, 55.1^{\circ}, 56.7^{\circ}, 59.7^{\circ}, 60.1^{\circ}, 61.5^{\circ}, 64.7^{\circ}, 70.4^{\circ}$ ) and the settled floc after $\mathrm{Al}_{2}\left(\mathrm{SO}_{4}\right)_{3}$ flocculation $\left(\mathrm{Al}_{2} \mathrm{O}_{3}: 32.3^{\circ}, 34.6^{\circ}, 36.9^{\circ}, 39.0^{\circ}, 45.0^{\circ}, 46.3^{\circ}\right.$, $\left.60.8^{\circ}, 67.8^{\circ}\right)$ by calcination at different temperatures

\subsection{Particle size distribution of metal oxides}

Figure 4 shows particle size distribution with different metal oxides produced from sludge. The majority of particles included a broad range of size distribution. $\mathrm{TiO}_{2}$ calcinated at $600{ }^{\circ} \mathrm{C}$ produced a high proportion of nm size particles $(10-25 \mathrm{~nm})$ of up to $25 \%$. Hematite $\left(\mathrm{Fe}_{2} \mathrm{O}_{3}\right)$ and grattarolaite $\left(\mathrm{Fe}_{3}\left(\mathrm{PO}_{4}\right) \mathrm{O}_{3}\right.$ or $\left.\mathrm{Fe}_{3} \mathrm{PO}_{7}\right)$ produced by Fe-salt flocculation $\left(700{ }^{\circ} \mathrm{C}\right.$ calcination) consisted of nano size particles $(5 \%)$ and $2.75 \mu \mathrm{m}$ micro size particles (40\%). Alumina $\left(\mathrm{Al}_{2} \mathrm{O}_{3}\right)$ from $\mathrm{Al}$-salt floc $\left(1000{ }^{\circ} \mathrm{C}\right.$ calcination) consisted of nano size particles (5\%) and 2. $75 \mu \mathrm{m}$ micro size particles (40\%). Since $\mathrm{TiO}_{2}$ is an attractive material due to its chemical stability, low cost and non-toxic properties, this study concentrated on $\mathrm{TiO}_{2}$ nanoparticles in terms of the effect of different temperatures.

\subsection{IR and optical property of $\mathrm{TiO}_{2}$}

The FTIR spectra of different $\mathrm{TiO}_{2}$ powders after calcination are depicted from $4000 \mathrm{~cm}^{-1}$

to $700 \mathrm{~cm}^{-1}$ in Figure 5. It is well known that the variation modes of anatase skeletal O-Ti- 
O bonds are observed in the range of $500-900 \mathrm{~cm}^{-1}$, with a maximum at $474 \mathrm{~cm}^{-1}$ [6;7;8;9]. Commonly, the IR spectrum at about $3500 \mathrm{~cm}^{-1}$, indicated the OH-stretching vibrations of free and hydrogen-bonded surface hydroxyl groups [6]. This suggests that water molecules are probably attached to $\mathrm{TiO}_{2}$ surface with $\mathrm{OH}$-stretching. The IR spectrum at around $1636 \mathrm{~cm}^{-1}$, was also water-related functional group (H-O-H bending). However, at $100{ }^{\circ} \mathrm{C}$ calcination, three main spectra were found at $1360 \mathrm{~cm}^{-1}, 1425 \mathrm{~cm}^{-1}$ and $1220 \mathrm{~cm}^{-1}$ (Table 2).

Figure 4. Particle size distribution of (a) titanium oxide at $600{ }^{\circ} \mathrm{C}$, (b) hematite and grattarolaite at $700{ }^{\circ} \mathrm{C}$ and (c) alumina at $1000^{\circ} \mathrm{C}$

Figure 5. FTIR spectra of $\mathrm{TiO}_{2}$ powders after calcination at different temperatures

Table 2. FTIR analyses at $100{ }^{\circ} \mathrm{C}$ calcinations of Ti-salt floc

Figure 6 shows UV-visible absorption of P-25 and the different $\mathrm{TiO}_{2}$ at different temperatures. P-25 photocatalyst absorbed the majority of UV light (less than $417 \mathrm{~nm}$ wavelength). However, the onset of the absorption spectrum of $\mathrm{TiO}_{2}$, calcination at 600 ${ }^{\circ} \mathrm{C}, 800{ }^{\circ} \mathrm{C}$ and $1000{ }^{\circ} \mathrm{C}$ appeared at $407 \mathrm{~nm}, 407 \mathrm{~nm}$ and $430 \mathrm{~nm}$, respectively. The band gap was $3.18 \mathrm{eV}$ (P-25), $3.05 \mathrm{eV}$ (after $600{ }^{\circ} \mathrm{C}$ ), $3.05 \mathrm{eV}$ (after $800{ }^{\circ} \mathrm{C}$ ) and 2.89 eV (after $1000{ }^{\circ} \mathrm{C}$ ), respectively.

Figure 6. UV-visible absorption spectra of $\mathrm{TiO}_{2}$ at $\mathrm{P}-25,600,800$ and 1000 photocatalysts 


\subsection{SEM/EDX result}

Table 3 shows atomic and weight percentage of the $\mathrm{TiO}_{2}$ powders produced after different temperatures by EDX results. The carbon sources remained in all the ranges of different temperatures. The $\mathrm{Ti}, \mathrm{C}, \mathrm{O}$ and $\mathrm{P}$ atoms were mainly detected. In addition, many different trace elements ( $\mathrm{Si}, \mathrm{Fe}, \mathrm{Al}, \mathrm{V}, \mathrm{Ca}, \mathrm{Na}, \mathrm{Cr}, \mathrm{Cl}, \mathrm{S}, \mathrm{Ni}$, and $\mathrm{Br}$ ) were found. Equation 1 shows the mass balance:

$(\mathrm{Ti} \text { input })_{\text {Theoretical }}-0.6085 *(\mathrm{TiO} 2-\text { output })_{\text {Theoretical }}=(\mathrm{Ti} \text { input })_{\text {Experimental }} \quad-$ 0.6085*(Particle production) $)_{\text {Experimental }}+$ Impurity

Here, $9.8 \mathrm{mg}$ of $\mathrm{Ti}$ concentration was dosed and $17.86 \mathrm{mg}$ of $\mathrm{TiO}_{2}$ was experimentally recovered. Thus, the impurity was $1.78 \mathrm{mg}$ in particles used in this study. The percentage of the impurity was $9.97 \%$. However, in this study, four main elements are mainly handled, which are Ti, O, C and P. Here, the carbon compounds may be due to the remaining carbon from the settled organic floc, which was not volatile to carbon dioxide and water. The averaged elemental content at $100{ }^{\circ} \mathrm{C}, 200^{\circ} \mathrm{C}, 400{ }^{\circ} \mathrm{C}, 600^{\circ} \mathrm{C}$, $800{ }^{\circ} \mathrm{C}$ and $1000{ }^{\circ} \mathrm{C}$ in terms of Ti:O:C:P was 10.0:59.4:28.9:1.8, 11.2:61.4:26.0:1.36, 13.0:61.9:2.0:2.1, 13.2:64.6:19.8:2.4, 17.0:68.5:12.1:2.4 and 17.7:70.7:10.4:1.2, respectively.

Table 3. Atomic and weight (\%) percentage of powders at different temperatures with $\pm 3.5 \%$ of standard deviation (weight \% (atomic \%) of P25: $\mathrm{Ti}=47.22 \%(23.02 \%)$ and $\mathrm{O}=52.78 \%(76.98 \%)$ 


\subsection{Photocatalytic activity}

The photocatalytic activity test with $\mathrm{P}-25$ and $\mathrm{TiO}_{2}$ produced from the Ti-salt sludge $\left(600{ }^{\circ} \mathrm{C}, 800{ }^{\circ} \mathrm{C}\right.$ and $1000{ }^{\circ} \mathrm{C}$ calcination) was investigated under irradiation of UV (Sankyo, F10T8BLB, three $10 \mathrm{~W}$ lamps) and visible light (Kumbo, FL10D, three 10W lamps) using the method of photodecomposition of gaseous acetaldehyde (Figure 7). As the BET surface area of $\mathrm{TiO}_{2}$ after $600{ }^{\circ} \mathrm{C}\left(76.3 \mathrm{~m}^{2} / \mathrm{g}\right), 800{ }^{\circ} \mathrm{C}\left(5.96 \mathrm{~m}^{2} / \mathrm{g}\right)$ and $1000{ }^{\circ} \mathrm{C}$ $\left(0.74 \mathrm{~m}^{2} / \mathrm{g}\right)$ was very different, the amount of $\mathrm{TiO}_{2}$ used in the experiments was varied to achieve a constant amount of removal (20\%) of acetaldehyde during TiO2 adsorption following which it was irradiated with UV light. The concentration of acetaldehyde was measured by gas chromatography (Youngin, M600D). Photocatalytic removal of acetaldehyde with $\mathrm{TiO}_{2}$ after $600{ }^{\circ} \mathrm{C}$ calcinations was higher than that with $\mathrm{P}-25$ under UV irradiation. On the other hand, photocatalytic removal with $\mathrm{TiO} 2$ after $800{ }^{\circ} \mathrm{C}$ and $1000{ }^{\circ} \mathrm{C}$ was lower than that with P-25. Although this figure is not shown, removal of acetaldehyde was small with all $\mathrm{TiO}_{2}$ under visible light.

Figure 7. Variation of $\mathrm{CH}_{3} \mathrm{CHO}$ concentration with irradiation time (initial concentration of $\mathrm{CH}_{3} \mathrm{CHO}=1000 \mathrm{mg} / \mathrm{L}$; UV irradiation = black light three $10 \mathrm{~W}$ lamps; visible light irradiation = fluorescent light at $436 \mathrm{~nm}$ and a light power of $0.9 \mathrm{~mW} / \mathrm{cm}^{2}$ )

\section{Conclusions}


A detailed experimental study was conducted with $\mathrm{Fe}, \mathrm{Al}$ and $\mathrm{Ti}$ salt coagulant to investigate their ability to remove organic matter, settling floc (sludge) and recycling sludge by calcination. The results led to the following conclusions:

1. Removals of organic matter by $\mathrm{Fe}, \mathrm{Al}$ and Ti-salt flocculation at optimum concentration were $73 \%, 70 \%$ and $70 \%$, respectively. The Fe floc settled quickly compared with $\mathrm{Ti}$ and $\mathrm{Al}$ flocs. The decantability decreased in the order of $\mathrm{Fe}$ floc $>\mathrm{Ti}>$ Al.

2. After calcination of the settled floc, Ti floc produced titanium oxide $\left(\mathrm{TiO}_{2}\right)$, Fe floc formed hematite $\left(\mathrm{Fe}_{2} \mathrm{O}_{3}\right)$ and grattarolaite $\left(\mathrm{Fe}_{3}\left(\mathrm{PO}_{4}\right) \mathrm{O}_{3}\right.$ or $\left.\mathrm{Fe}_{3} \mathrm{PO}_{7}\right)$, and $\mathrm{Al}$ floc created alumina $\left(\mathrm{Al}_{2} \mathrm{O}_{3}\right)$.

3. $\mathrm{TiO}_{2}$ produced from the sludge consisted of the large amount of nano size particles. Hematite $\left(\mathrm{Fe}_{2} \mathrm{O}_{3}\right)$ and grattarolaite $\left(\mathrm{Fe}_{3}\left(\mathrm{PO}_{4}\right) \mathrm{O}_{3}\right.$ or $\left.\mathrm{Fe}_{3} \mathrm{PO}_{7}\right)$ mostly included 2. $75 \mu \mathrm{m}$ micro size particles (40\%). Alumina $\left(\mathrm{Al}_{2} \mathrm{O}_{3}\right)$ consisted of micro size particles (40\%).

4. The percentage of the impurity of $\mathrm{TiO}_{2}$ produced by the settled floc was $9.97 \%$. According to SEM/EDX elemental results, Ti, O, C and P elemental contents on/in $\mathrm{TiO}_{2}$ were significantly changed at different temperatures. Photoactivity of $\mathrm{TiO}_{2}$ at different temperatures was significantly varied. At $600{ }^{\circ} \mathrm{C}$ cacination, the photoactivity was very high. On the other hand, at 800 and $1000{ }^{\circ} \mathrm{C}$, the photoactivity was marginal compared with that of $\mathrm{P}-25$ photocatalyst. 
This study has significant potentials to minimize a large amount of sludge from water treatment plants. The recovered sludge can be converted to useful metal oxides which are titanium dioxide, hematite and alumina. The significant quantities of metal oxides can be applied to environmental remediation, construction material and energy production.

\section{Acknowledgements}

This research was funded by CRC-CARE in Australia and the Korea Research Foundation Grant in the Korean Government (KRF-2007-412-J02002). The authors appreciate the support from the Center for Photonic Materials and Devices at Chonnam National University .

\section{References}

[1] H.K. Shon, S. Vigneswaran, S.A. Snyder, Cri. Rev. Env. Sci. Tec. 36, (2006), 327.

[2] J. DeWolfe, B. Dempsey, M. Taylor, J.W. Potter, J.W. Guidance manual for coagulant changeover, American Water Works Association Press, Denver, 2002.

[3] H.K. Shon, S. Vigneswaran, I.S. Kim, J. Cho, G.J. Kim, J.B. Kim, J.-H. Kim, Environ. Sci. Tech. 41, (2007), 1372.

[4] T. Kapias, R.F. Griffiths, J. Hazard. Mater. 119, (2005), 41.

[5] G.T. Seo, S. Ohgaki, Y. Suzuki, Water Sci. Technol. 35, (1997), 163.

[6] D. Dvoranová, V. Brezová, M. Mazúr, M.A. Malati, Appl. Catal. B-Environ. 37, (2002), 91. 
[7] G. Cristallo, E. Roncari, A. Rinaldo, Appl. Catal. A-Gen, 209, (2001), 249.

[8] J.M. Gallardo-Amores, T. Armaroli, G. Ramis, E. Finocchio, G. Buscak, Appl. Catal. B-Environ. 22, (1999), 249.

[9] S.Y. Kim, T.S. Chang, D.K. Lee, C.H. Shin, J. Ind. Eng. Chem., 11 (4), 495, 2005. 
Table 1. Constituents of the synthetic wastewater

Table 2. FTIR analyses at $100{ }^{\circ} \mathrm{C}$ calcinations of Ti-salt floc

Table 3. Atomic and weight (\%) percentage of powders at different temperatures with $\pm 3.5 \%$ of standard deviation (weight \% (atomic \%) of P25: $\mathrm{Ti}=47.22 \%(23.02 \%)$ and $\mathrm{O}=52.78 \%(76.98 \%))$ 
Table 1. Constituents of the synthetic wastewater

\begin{tabular}{lccc}
\hline \multicolumn{1}{c}{ Compounds } & Concentration & Molecular weight & Fraction by \\
& $(\mathrm{mg} / \mathrm{L})$ & (daltons) & organic \\
& & & concentration \\
\hline Beef extract & 1.8 & $300,100,70$ & 0.065 \\
Peptone & 2.7 & $34300,100,80$ & 0.138 \\
Humic acid & 4.2 & 1500,300 & 0.082 \\
Tannic acid & 4.2 & 6300 & 0.237 \\
Sodium lignin sulfonate & 2.4 & 12100 & 0.067 \\
Sodium lauryle sulphate & 0.94 & 34300 & 0.042 \\
Arabic gum powder & 4.7 & 900,300 & 0.213 \\
Arabic acid (polysaccharide) & 5.0 & 38900 & 0.156 \\
$\left(\mathrm{NH}_{4}\right)_{2} \mathrm{SO}_{4}$ & 7.1 & & 0 \\
$\mathrm{~K}_{2} \mathrm{HPO}_{4}$ & 7.0 & & 0 \\
$\mathrm{NH}_{4} \mathrm{HCO}_{3}$ & 0.71 & & 0 \\
$\mathrm{MgSO}_{4} \cdot 7 \mathrm{H}_{2} \mathrm{O}$ & & & 0 \\
\hline
\end{tabular}


Table 2. FTIR analyses at $100{ }^{\circ} \mathrm{C}$ calcinations of Ti-salt floc
$1220 \mathrm{~cm}^{-1} \quad$ 1) $1260-1180 \mathrm{~cm}^{-1}$ : alcohol (phenol-OH)
2) $1240-1170 \mathrm{~cm}^{-1}:$ Amines $\left(\mathrm{R}_{2}-\mathrm{C}-\mathrm{NH}_{2}\right)$
$1360 \mathrm{~cm}^{-1} \quad$ Carbonate [6]
$1425 \mathrm{~cm}^{-1}$ 1) $1440-1405 \mathrm{~cm}^{-1}$ : phosphorus ((RR'R') $\mathrm{P}=\mathrm{OP}-\mathrm{CH}_{2}$
2) $1440-1395 \mathrm{~cm}^{-1}$ : carbo acid $(\mathrm{COOH})$ 
Table 3. Atomic and weight (\%) percentage of powders at different temperatures with $\pm 3.5 \%$ of standard deviation (weight $\%$ (atomic \%) of P25: $\mathrm{Ti}=47.22 \%(23.02 \%)$ and $\mathrm{O}=52.78 \%(76.98 \%))$

\begin{tabular}{|c|c|c|c|c|c|c|}
\hline & $100{ }^{\circ} \mathrm{C}$ & $200{ }^{\circ} \mathrm{C}$ & $400^{\circ} \mathrm{C}$ & $600{ }^{\circ} \mathrm{C}$ & $800{ }^{\circ} \mathrm{C}$ & $1000^{\circ} \mathrm{C}$ \\
\hline C Atomic & 28.85 & 26.04 & 23.00 & 19.75 & 12.08 & 10.38 \\
\hline
\end{tabular}

(\%)

$\begin{array}{lllllll}\text { Weight } & 18.83 & 16.69 & 14.00 & 11.99 & 7.15 & 5.88\end{array}$

(\%)

$\begin{array}{llllllll}\text { O } & \text { Atomic } & 59.39 & 61.37 & 61.92 & 64.62 & 68.50 & 70.66\end{array}$

(\%)

$\begin{array}{lllllll}\text { Weight } & 51.64 & 52.39 & 50.21 & 52.26 & 54.03 & 53.31\end{array}$

(\%)

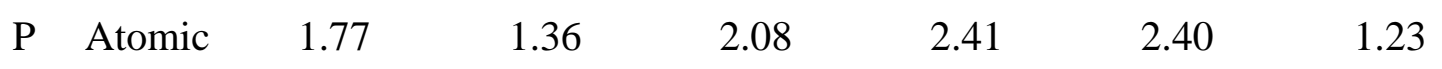

(\%)

$\begin{array}{lllllll}\text { Weight } & 2.98 & 2.24 & 3.27 & 3.78 & 3.67 & 1.80\end{array}$

(\%)

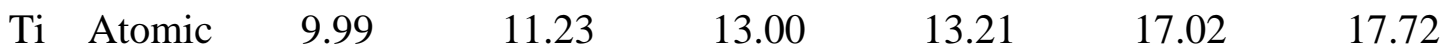

(\%)

$\begin{array}{lllllll}\text { Weight } & 25.99 & 28.68 & 31.55 & 31.97 & 40.16 & 40.00\end{array}$

(\%)

* Trace elements found: Si (0.2\%), Fe (0.02\%), S (0.01\%), Al (0.01), V, Ca, Na, Cr, Cl, $\mathrm{Ni}$, and $\mathrm{Br}$ 
Figure 1. Organic removal by different flocculations with synthetic wastewater (initial organic conc. $=11.5 \mathrm{mg} / \mathrm{L})$

Figure 2. Decantability ratio of different flocs

Figure 3. XRD images a) of the settled floc after $\mathrm{TiCl}_{4}$ flocculation, b) of the settled floc after $\mathrm{FeCl}_{3}$ flocculation (hematite $\left(\mathrm{Fe}_{2} \mathrm{O}_{3}\right): 24^{\circ}, 33^{\circ}, 35^{\circ}, 40.5^{\circ}, 49.4^{\circ}, 54^{\circ}, 57.5^{\circ}, 62.5^{\circ}$, $63.9^{\circ}, 71.8^{\circ}, 75.3^{\circ}$; grattarolaite $\left(\mathrm{Fe}_{3}\left(\mathrm{PO}_{4}\right) \mathrm{O}_{3}\right.$ or $\left.\mathrm{Fe}_{3} \mathrm{PO}_{7}\right): 18.2^{\circ}, 28.9^{\circ}, 36.8^{\circ}, 38.9^{\circ}$, $43.3^{\circ}, 45.3^{\circ}, 45.6^{\circ}, 49.2^{\circ}, 55.1^{\circ}, 56.7^{\circ}, 59.7^{\circ}, 60.1^{\circ}, 61.5^{\circ}, 64.7^{\circ}, 70.4^{\circ}$ ) and the settled floc after $\mathrm{Al}_{2}\left(\mathrm{SO}_{4}\right)_{3}$ flocculation $\left(\mathrm{Al}_{2} \mathrm{O}_{3}: 32.3^{\circ}, 34.6^{\circ}, 36.9^{\circ}, 39.0^{\circ}, 45.0^{\circ}, 46.3^{\circ}\right.$, $60.8^{\circ}, 67.8^{\circ}$ ) by calcination at different temperatures

Figure 4. Particle size distribution of (a) titanium oxide at $600{ }^{\circ} \mathrm{C}$, (b) hematite and grattarolaite at $700{ }^{\circ} \mathrm{C}$ and (c) alumina at $1000^{\circ} \mathrm{C}$

Figure 5. FTIR spectra of $\mathrm{TiO}_{2}$ powders after calcination at different temperatures

Figure 6. UV-visible absorption spectra of $\mathrm{TiO}_{2}$ at $\mathrm{P}-25,600,800$ and 1000 photocatalysts

Figure 7. Variation of $\mathrm{CH}_{3} \mathrm{CHO}$ concentration with irradiation time (initial concentration of $\mathrm{CH}_{3} \mathrm{CHO}=1000 \mathrm{mg} / \mathrm{L}$; UV irradiation = black light three $10 \mathrm{~W}$ lamps; visible light irradiation = fluorescent light at $436 \mathrm{~nm}$ and a light power of $0.9 \mathrm{~mW} / \mathrm{cm}^{2}$ ) 


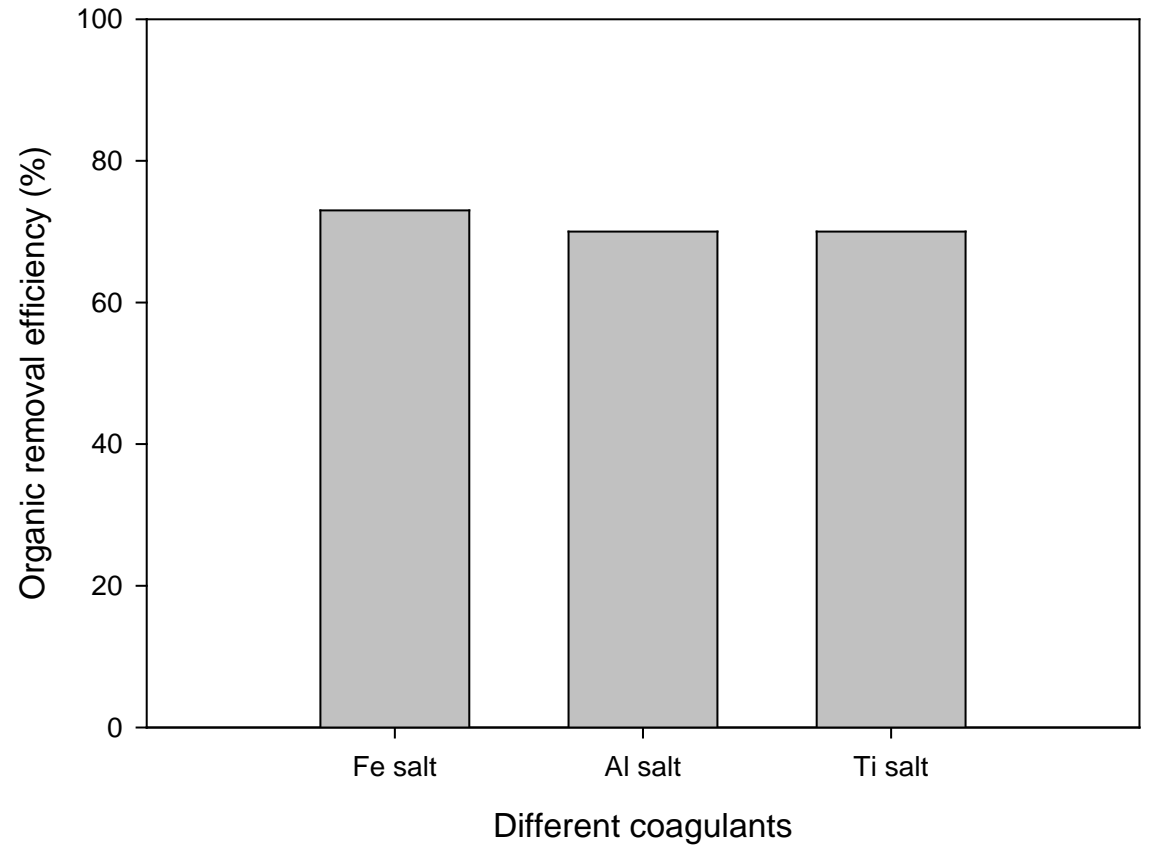

Figure 1. Organic removal by different flocculations with synthetic wastewater (initial organic conc. $=11.5 \mathrm{mg} / \mathrm{L}$ ) 


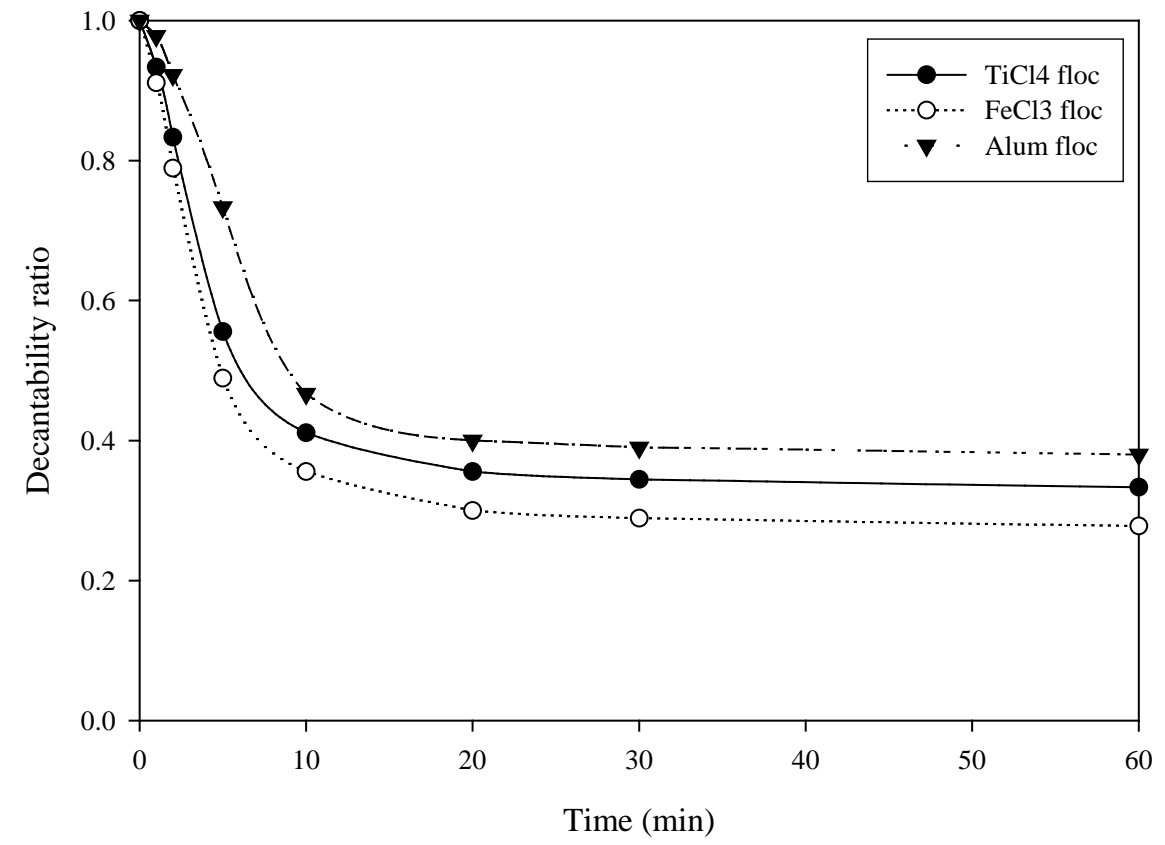

Figure 2. Decantability ratio of different flocs 


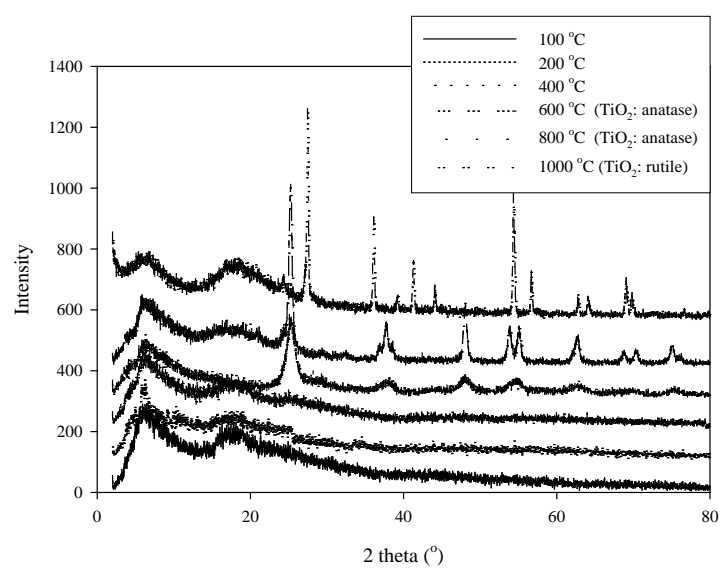

a)

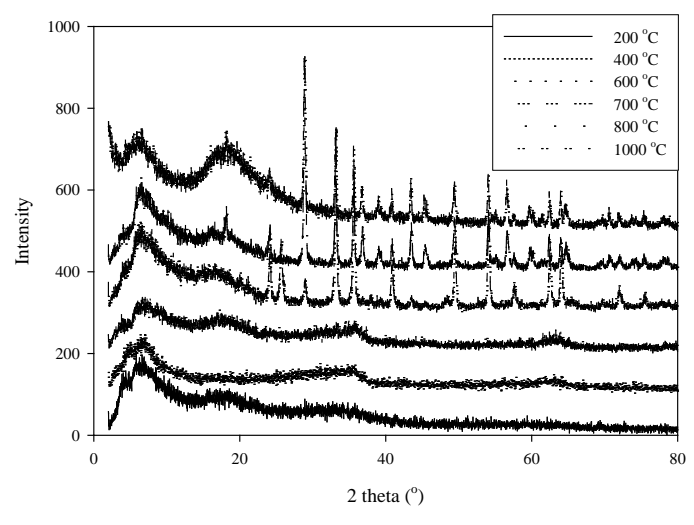

b)

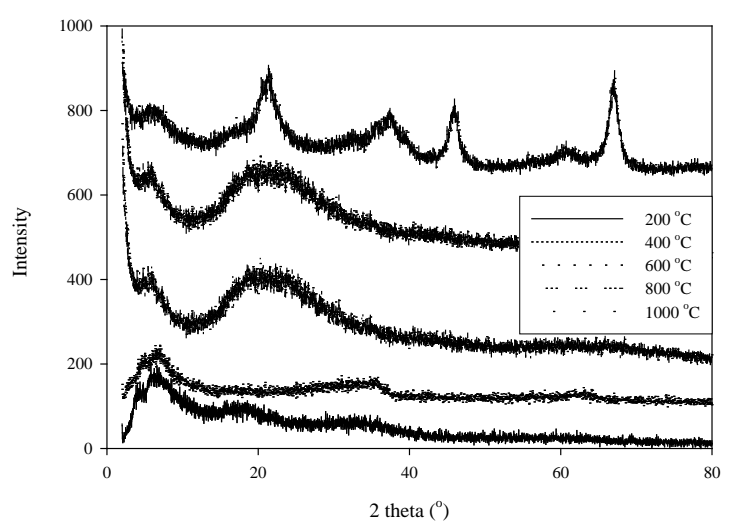

c)

Figure 3. XRD images a) of the settled floc after $\mathrm{TiCl}_{4}$ flocculation, b) of the settled floc after $\mathrm{FeCl}_{3}$ flocculation (hematite $\left(\mathrm{Fe}_{2} \mathrm{O}_{3}\right)$ : $24^{\circ}, 33^{\circ}, 35^{\circ}, 40.5^{\circ}, 49.4^{\circ}, 54^{\circ}, 57.5^{\circ}, 62.5^{\circ}$, $63.9^{\circ}, 71.8^{\circ}, 75.3^{\circ}$; grattarolaite $\left(\mathrm{Fe}_{3}\left(\mathrm{PO}_{4}\right) \mathrm{O}_{3}\right.$ or $\left.\mathrm{Fe}_{3} \mathrm{PO}_{7}\right): 18.2^{\circ}, 28.9^{\circ}, 36.8^{\circ}, 38.9^{\circ}$, $43.3^{\circ}, 45.3^{\circ}, 45.6^{\circ}, 49.2^{\circ}, 55.1^{\circ}, 56.7^{\circ}, 59.7^{\circ}, 60.1^{\circ}, 61.5^{\circ}, 64.7^{\circ}, 70.4^{\circ}$ ) and the settled floc after $\mathrm{Al}_{2}\left(\mathrm{SO}_{4}\right)_{3}$ flocculation $\left(\mathrm{Al}_{2} \mathrm{O}_{3}: 32.3^{\circ}, 34.6^{\circ}, 36.9^{\circ}, 39.0^{\circ}, 45.0^{\circ}, 46.3^{\circ}\right.$, $60.8^{\circ}, 67.8^{\circ}$ ) by calcination at different temperatures 


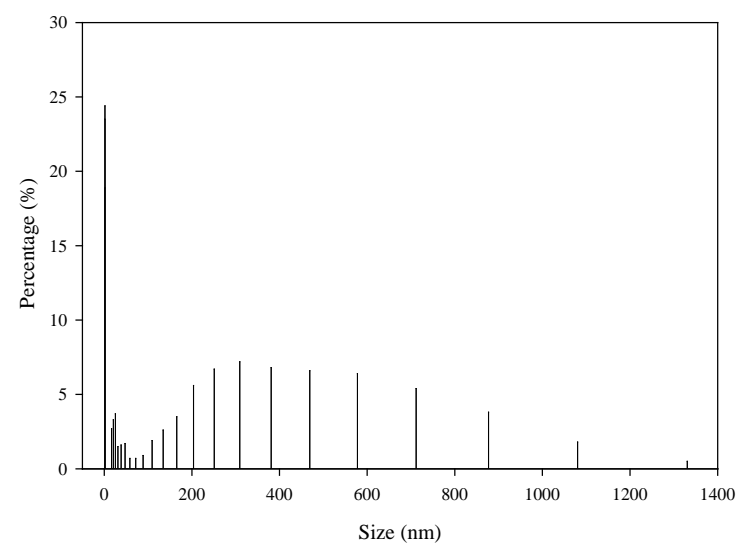

a)

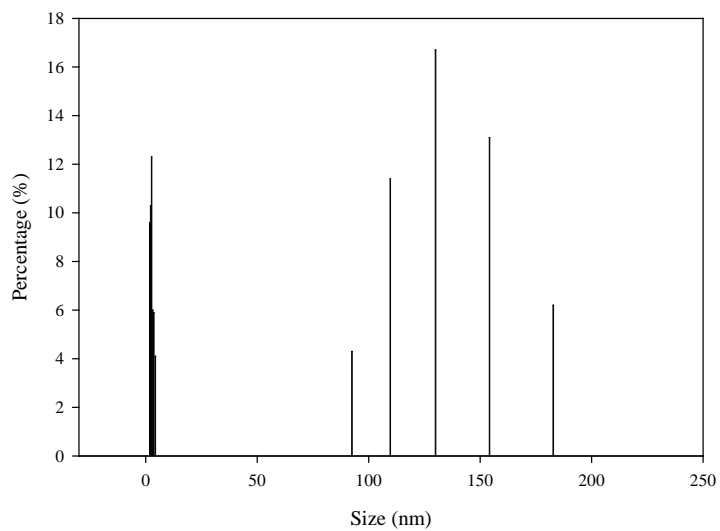

c)

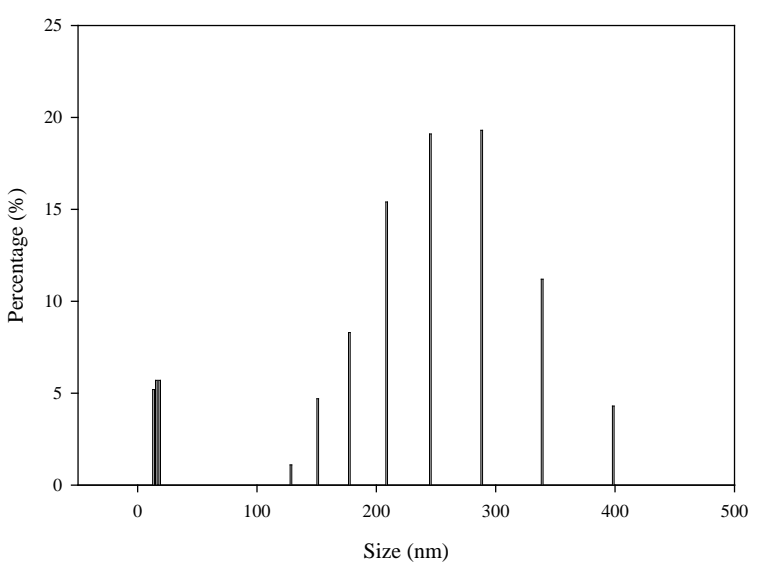

b)

Figure 4. Particle size distribution of (a) titanium oxide at $600{ }^{\circ} \mathrm{C}$, (b) hematite and grattarolaite at $700{ }^{\circ} \mathrm{C}$ and (c) alumina at $1000{ }^{\circ} \mathrm{C}$ 


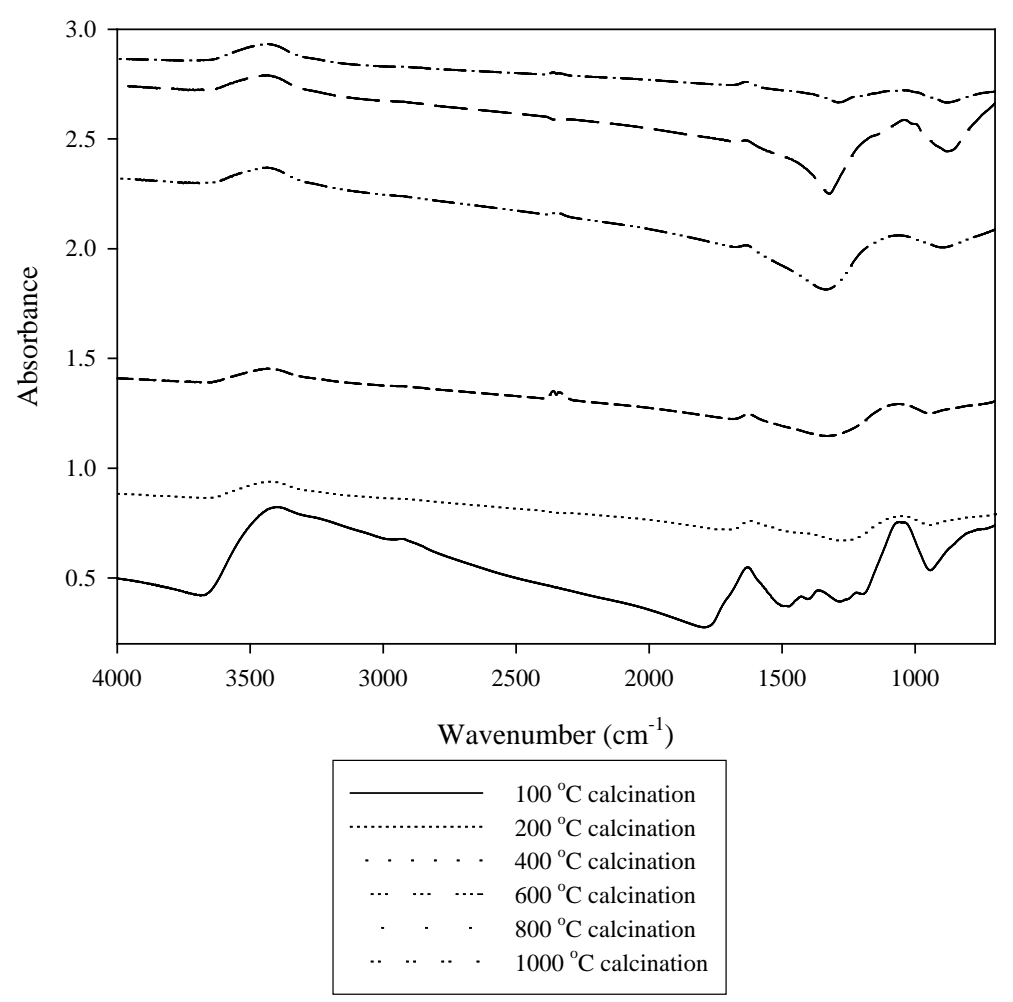

Figure 5. FTIR spectra of $\mathrm{TiO}_{2}$ powders after calcination at different temperatures 


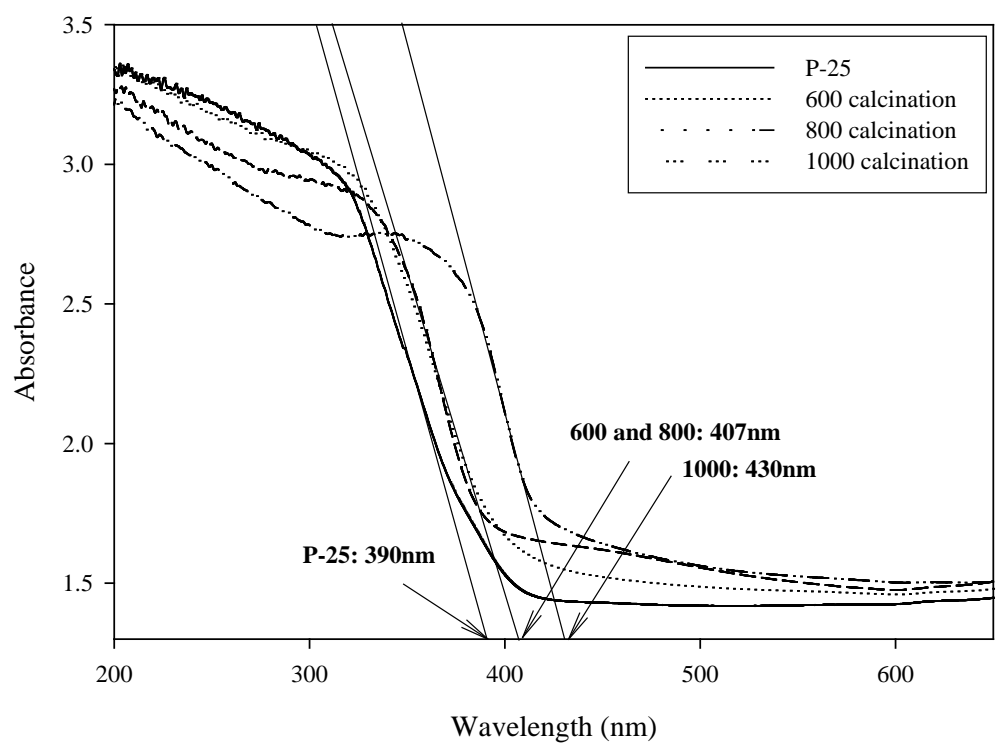

Figure 6. UV-visible absorption spectra of $\mathrm{TiO}_{2}$ at $\mathrm{P}-25,600,800$ and 1000 photocatalysts 


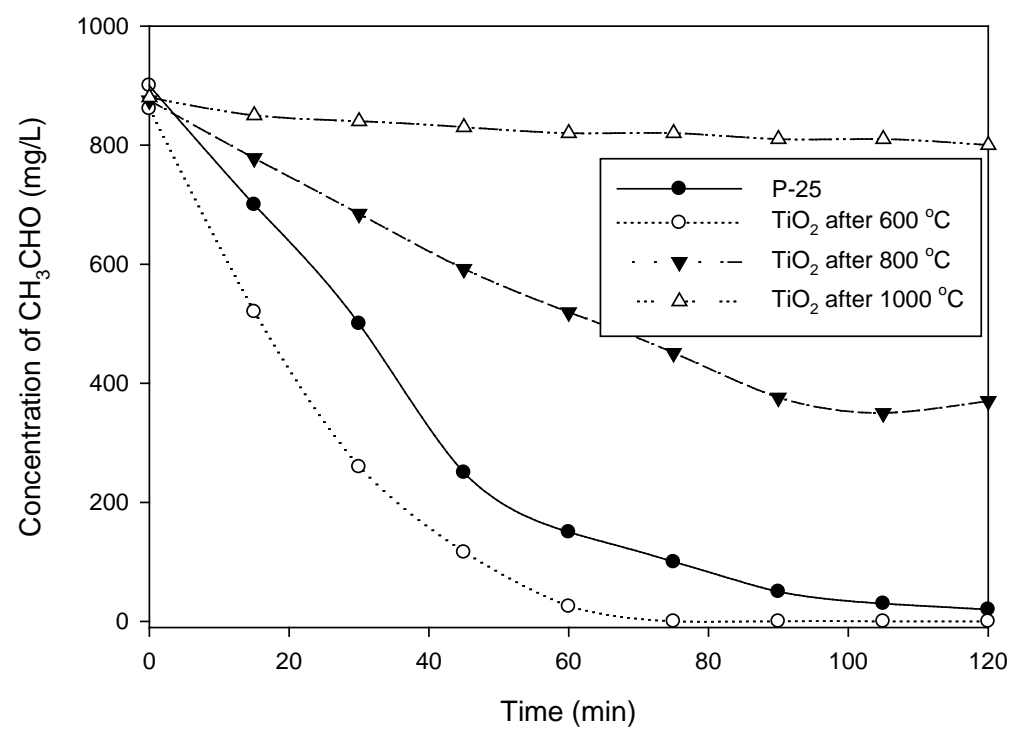

Figure 7. Variation of $\mathrm{CH}_{3} \mathrm{CHO}$ concentration with irradiation time (initial concentration of $\mathrm{CH}_{3} \mathrm{CHO}=1000 \mathrm{mg} / \mathrm{L}$; UV irradiation = black light three $10 \mathrm{~W}$ lamps; visible light irradiation = fluorescent light at $436 \mathrm{~nm}$ and a light power of $0.9 \mathrm{~mW} / \mathrm{cm}^{2}$ ) 